\title{
Introduction - Teaching European Studies: Educational challenges
}

Citation for published version (APA):

Baroncelli, S., Farneti, R., \& Vanhoonacker, S. M. R. L. (2013). Introduction - Teaching European Studies: Educational challenges. In S. Baroncelli, R. Farneti, I. Horga, \& S. M. R. L. Vanhoonacker (Eds.), Teaching and Learning the European Union. Traditional and Innovative Teaching Methods (pp. 1-6). Springer Verlag. Innovation and Change in Professional Education Vol. 9 https://doi.org/10.1007/978-94007-7043-0_1

Document status and date:

Published: 01/01/2013

DOI:

10.1007/978-94-007-7043-0_1

Document Version:

Version created as part of publication process; publisher's layout

Document license:

CC BY-NC-ND

\section{Please check the document version of this publication:}

- A submitted manuscript is the version of the article upon submission and before peer-review. There can be important differences between the submitted version and the official published version of record.

People interested in the research are advised to contact the author for the final version of the publication, or visit the DOI to the publisher's website.

- The final author version and the galley proof are versions of the publication after peer review.

- The final published version features the final layout of the paper including the volume, issue and page numbers.

Link to publication

\footnotetext{
General rights rights.

- You may freely distribute the URL identifying the publication in the public portal. please follow below link for the End User Agreement:

www.umlib.nl/taverne-license

Take down policy

If you believe that this document breaches copyright please contact us at:

repository@maastrichtuniversity.nl

providing details and we will investigate your claim.
}

Copyright and moral rights for the publications made accessible in the public portal are retained by the authors and/or other copyright owners and it is a condition of accessing publications that users recognise and abide by the legal requirements associated with these

- Users may download and print one copy of any publication from the public portal for the purpose of private study or research.

- You may not further distribute the material or use it for any profit-making activity or commercial gain

If the publication is distributed under the terms of Article $25 \mathrm{fa}$ of the Dutch Copyright Act, indicated by the "Taverne" license above, 
See discussions, stats, and author profiles for this publication at: https://www.researchgate.net/publication/319448157

\section{Teaching and Learning the European Union, Traditional and Innovative Methods}

Book - January 2014

DOl: 10.1007/978-94-007-7043-0

CITATIONS

17

4 authors, including:

Stefania Baroncelli

Free University of Bozen-Bolzano

8 PUBLICATIONS 34 CITATIONS

SEE PROFILE

Sophie Vanhoonacker

Maastricht University

61 PUBLICATIONS 765 CITATIONS

SEE PROFILE

Some of the authors of this publication are also working on these related projects:

The implementation of European Union Law in the EU member States View project
27 PUBLICATIONS 81 CITATIONS

SEE PROFILE 


\section{Metadata of the chapter that will be visualized online}

\begin{tabular}{|c|c|c|}
\hline Chapter Title & \multicolumn{2}{|c|}{ Introduction - Teaching European Studies: Educational Challenges } \\
\hline Copyright Year & \multicolumn{2}{|l|}{2014} \\
\hline Copyright Holder & \multicolumn{2}{|c|}{ Springer Science+Business Media Dordrecht } \\
\hline \multirow[t]{7}{*}{ Corresponding Author } & Family Name & Baroncelli \\
\hline & Particle & \\
\hline & Given Name & Stefania \\
\hline & Suffix & \\
\hline & Division & School of Economics \\
\hline & Organization & Free University of Bozen/Bolzano \\
\hline & Address & $\begin{array}{l}\text { Piazza Università 1, 39100, Bolzano, } \\
\text { Italy }\end{array}$ \\
\hline \multirow[t]{7}{*}{ Author } & Family Name & Farneti \\
\hline & Particle & \\
\hline & Given Name & Roberto \\
\hline & Suffix & \\
\hline & Division & School of Economics \\
\hline & Organization & Free University of Bozen/Bolzano \\
\hline & Address & $\begin{array}{l}\text { Piazza Università 1, 39100, Bolzano, } \\
\text { Italy }\end{array}$ \\
\hline \multirow[t]{7}{*}{ Author } & Family Name & Vanhoonacker \\
\hline & Particle & \\
\hline & Given Name & Sophie \\
\hline & Suffix & \\
\hline & Division & Faculty of Arts and Social Sciences \\
\hline & Organization & Maastricht University \\
\hline & Address & $\begin{array}{l}\text { 616, } 6200 \mathrm{MD} \text {, Maastricht, The } \\
\text { Netherlands }\end{array}$ \\
\hline
\end{tabular}

The increasing importance of the European Union as a central player in both domestic and international politics since the late 1980s has given a strong boost to an academic research agenda moving beyond nationoriented approaches (Keeler 2005). This development found promptly its way into university curricula, be it in economics, law, history, political science, cultural studies, IR and other programmes. These traditional disciplines saw the raise of new courses, specialised tracks and even entire master's programmes focusing on the impact of the EU on their respective discipline. In addition, the multifaceted character of the European integration process also led to the creation of new multiand interdisciplinary bachelor's, master's and even $\mathrm{PhD}$ programmes specifically focusing on the EU. These programmes were mostly labelled European Studies or European Union Studies. While the term European 
Studies.

\section{Author's Proof}

Studies could be considered to be broader in scope and reflecting an interest in the European continent in more general terms, in practice both terms are being used interchangeably. In the framework of this study, we have chosen for the most commonly used term of European Studies. If the author however specifically wanted to emphasise that a programme was exclusively focusing on the EU, we have allowed for the term EU

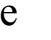

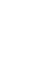

(n) 


\section{Chapter 1 \\ Introduction - Teaching European Studies: Educational Challenges}

The increasing importance of the European Union as a central player in both domestic and international politics since the late 1980s has given a strong boost to an

[AU2] academic research agenda moving beyond nation-oriented approaches (Keeler 2005). This development found promptly its way into university curricula, be it in economics, law, history, political science, cultural studies, IR and other programmes. These traditional disciplines saw the raise of new courses, specialised tracks and even entire master's programmes focusing on the impact of the EU on their respective discipline. In addition, the multifaceted character of the European integration process also led to the creation of new multi- and interdisciplinary bachelor's, master's and even PhD programmes specifically focusing on the EU. These programmes were mostly labelled European Studies or European Union Studies. While the term European Studies could be considered to be broader in scope and reflecting an interest in the European continent in more general terms, in practice both terms are being used interchangeably. In the framework of this study, we have chosen for the most commonly used term of European Studies. If the author however specifically wanted to emphasise that a programme was exclusively focusing on the EU, we have allowed for the term EU Studies.

The development of 'European Studies programmes', either within or beyond 22 strict disciplinary boundaries, did not take place in a vacuum. It was heavily 23 influenced by the rapidly changing European educational environment. The Bologna 24 process (1999) fostering increasing harmonisation of European educational 25

[AU3] S. Baroncelli $(\bowtie) \bullet$ R. Farneti

School of Economics, Free University of Bozen/Bolzano,

Piazza Università 1, 39100 Bolzano, Italy

e-mail: Stefania.Baroncelli@unibz.it; Roberto.Farneti@unibz.it

S. Vanhoonacker

Faculty of Arts and Social Sciences, Maastricht University, P.O. Box 616,

6200 MD, Maastricht, The Netherlands

e-mail: s.vanhoonacker@maastrichtuniversity.nl 


\section{Author's Proof}

systems and quality standards, the Lisbon agenda (2000) with its emphasis on the development of a knowledge-based economy and the boom in information technology all stimulated universities to critically reflect on the set-up of their curricula, not only in terms of content but also pedagogy. Although both dimensions are closely interconnected, the main emphasis of this volume will be on the pedagogical dimension. Inspired by educational scholars urging to move beyond traditional knowledge-based learning (knowing that) and advocating a 'learning to learn paradigm' with emphasis on a more pragmatic problem-solving and problem-based learning (knowing how) (Bleiklie and Henkel 2005), the various contributions on this volume try to bring a better understanding of the educational challenges and needs in the field of European Studies, map the state of the art of the teaching methodologies currently used and share experiences about innovative teaching methods. It not only examines inter- and multidisciplinary programmes but has also looked at curricula where the EU is taught as a horizontal topic in more conventional programmes such as law and economics.

The educational challenges facing European Studies ${ }^{1}$ are far from unique, and many of the questions discussed in this volume are also relevant for other programmes of higher education. As an emerging field, it is, however, particularly appealing as a particularly interesting area of investigation and scholarly concern. There is a lively debate about the knowledge, competencies and skills it should foster (Wessels et al. 2001; Smith 2003; Calhoun 2003; Cini 2006; Cini and Bourne 2006; Rosamond 2007; Holland et al. 2008), and in the absence of a long-standing tradition, it has been an attractive laboratory for trying out novel and uncharted pedagogical tools (Korosteleva 2010). Being a new area, it has shown particular concern as to how to best prepare its graduates for the rapidly changing Europeanwide job market. Dealing with a subject that goes beyond national borders, it has further been open to exchange of students and teaching staff, stimulating an international exchange of views and teaching in a second language (mainly English). The exclusive focus on educational experiences in European Studies allows the rather diverse chapters to 'speak to each other', and it allows to bring together experiences of colleagues operating in relatively similar contexts.

Given the rather wide scope of questions, the volume is organised in three parts. The first part deals with the broader contexts of teaching and learning within the EU and explores some of the challenges involved, paying special attention to the issue of professional education. The second part presents the results of a mapping exercise of teaching methods in EU Studies based on an extensive survey conducted by the University of Bozen/Bolzano. In the third part, academics teaching on European Studies programmes share some of their experiences with the use of innovative teaching tools and provide a platform for the exchange of best practices. Most of the chapters were originally presented and discussed in three workshops ${ }^{2}$ organised in

\footnotetext{
${ }^{1}$ In this volume both the terms European Union Studies and European Studies (ES) will be used. ${ }^{2}$ The workshops took place in Forli (16-18 March 2008), Oradea (28-29 May 2009), and Rome (2 July 2010).
} 


\section{Author's Proof}

1 Introduction - Teaching European Studies: Educational Challenges

the framework of the SENT network, a European-wide network of 66 universities involved in teaching European Studies (see also the preface to this publication). ${ }^{3}$

The first part of the volume is undoubtedly the most diverse, dealing with questions ranging from the professional requirements for graduates in EU Studies to issues of civic education and multilingual teaching. The opening chapter, by Wim Gijselaers et al., looks at European Studies from the perspective of professional education. The authors examine the literature on professional education and examine how insights from established professions such as medicine can be of use to new professions such as EU specialists. They not only plead to engage the learner more actively in the learning process but also advocate more educational research and more attention on guiding learners so that they can deal with the continuous changes in practice. David Bearfield, the Director of the European Personnel Selection Office (EPSO), elaborates on the recently reformed HR selection strategy for staff at EU institutions. He shows how the new EPSO Development Programme has contributed to modernising the EU institutions' selection methods so that human capital and management potential can be more effectively detected, which ultimately provides new cohorts of motivated and talented staff. Gretchen Van Dyke focuses on active learning as a critical resource for both educational and civic purposes. She stresses the value of active and experiential learning in engaging students as citizens of Europe. Building upon her experience with civic education in the USA, she examines what is needed at the classroom level to help EU Studies students to connect academic learning with the practical realities of EU citizenship. Rita Franceschini and Daniela Veronesi address the sensitive topic of multilingual universities. They use the notion of 'functional multilingualism' to examine the role of linguistic diversity in shaping the EU public sphere. They analyse communicative practices in multilingual universities and present a case study on the trilingual Free University of Bozen/Bolzano in northern Italy, where multilingualism is used as a key instrument to prepare future professionals to successfully operate in a multilingual and multicultural Europe. The chapter by Eduard Lavalle and Alexander Berlin illustrates an EU Study Tour and Internship programme for Canadian students and elaborates on the social and cultural implications of circulating human capital within the Union. The programme, now in its ninth year, has provided innovative opportunities for students to strengthen their knowledge of the EU, with practical immersion, hands-on experience and 'face-to-face' contact with professionals actively involved in the day-to-day work of EU institutions. It is a means of socialisation, but it is also a way to initiate students with a non-EU background into the 'new' EU professions.

Part II presents an empirical analysis of the use of teaching methods and tools in EU studies across a number of disciplines (Economics, Law, History, Political Science, and Cultural studies). Secondly it also tests the influence of multilingualism on European Studies courses. The three chapters are all based on the results of a survey conducted on more than 2,000 EU courses in 30 European countries and 


\section{Author's Proof}

7 different disciplines via the abovementioned SENT European Studies network and the Jean Monnet Programme network. The chapter by Baroncelli, Fonti and Stevancevic maps the use of innovative learning methodologies such as teamwork, the role of experts, field work, simulations, project-based approach, long-distance learning, peer tutoring, internships, exchange programmes and e-learning. They explore the link between the use of new methodologies and demographic and personal characteristics of the lecturers involved. Their overview shows that there is still a long way to go with regard to the use of innovative teaching tools, especially in terms of diversification. The chapter by Fonti and Stevancevic builds on the previous one by looking more into detail into the innovative methods of internships, distance learning and exchange programmes. Using statistical techniques, they investigate how factors such as group size, experience and position of teaching staff, size of class and presence of teaching evaluations correlate with the increased use of these methods. The third chapter, by Stefania Baroncelli, deals with the promotion of multilingualism in European Studies. She argues that, despite its obvious commitment to linguistic pluralism, the EU promotes multilingualism mainly at the level of EU legislation and political institutions. The EU lacks a more ambitious policy on linguistic pluralism, a politics of multilingualism that may affect the very relationship between EU citizens and EU institutions and impact on the identity of the EU. Based on the survey's findings, the author discusses the role of the EU in promoting teaching and learning in English and other EU languages other than English and advocates a more active role of the EU in promoting language pluralism in the classroom.

Part III elaborates on the use of innovative teaching methods in EU studies and presents a number of case studies on the use of simulation games, distance learning, problem-based learning, blended learning, the use of social media and internships. The contributors share their experiences with the use of these tools and reflect on both the strengths and possible pitfalls. Rebecca Jones and Peter Bursens deal with the use of simulations as a way to increase a type of learning that the authors call 'affective', involving the emotional sphere of the participants in the learning process. Their chapter presents a case study on EuroSim, a yearly organised simulation game taking place in the framework of the Trans-Atlantic Consortium for European Union Studies and Simulations (TACEUSS). By conducting pre- and postsimulation surveys, they empirically test the learning effect of this teaching tool. Natalia Timus explores the use of distance learning (DL) by surveying its most popular techniques. Based on the analysis of the advantages and limitations of DL, and with a special focus on the case study of a graduate course on 'EU-Turkey relations' at Maastricht University, she argues that DL provides an important space for innovation in learning and makes the learning process more accessible. She also shows how DL provides a framework for interuniversity cooperation and a platform for exchanging the best teaching and learning practices. Heidi Maurer and Christine Neuhold focus on the strengths and challenges of using problem-based learning (PBL) in the field of the European Studies. PBL is based on the idea of small group collaborative learning with students being actively responsible for their own learning process. Drawing on their experience in the Bachelor ES at Maastricht University, 


\section{Author's Proof}

1 Introduction - Teaching European Studies: Educational Challenges

they look at the possible pitfalls of the method with a particular focus on the role of tutors and the design of assignments. Alexandra Mihai presents a case of 'blended learning' (BL) as applied by the Institute for European Studies (IES) in Brussels and combining the e-learning tool of E-modules with face-to-face training sessions and webinars (i.e. web seminars). An important strength of BL is that it is a flexible tool that can be adapted to the target group, be it regular students or professionals. Each medium can be used for the functions it is best designed for so that the various pieces of the 'pedagogical puzzle' fit together. The chapter by Roberto Farneti et al. makes a case for the use of social networks in the classroom. The chapter draws on a pilot project using an electronic forum in a political science class. Students were challenged to respond to a 'prompt' from the instructor on topical issues in EU politics and to engage in informed discussion in class. The forum prescribes a method of discussion and critique and presents itself as a miniature of the democratic 'public sphere'. This article is linked to Gretchen van Dyke's chapter on civic education in this volume and connects current issues and challenges in higher education with the ever more relevant problem of the 'democratic deficit' of the EU. The final chapter deals with the use of internships as an instrument of learning.

The names of those who helped us to complete this book by way of discussion and criticism are too numerous to record. Our primary debt is to the scholars who contributed to the volume and patiently bore with us by integrating our comments into their chapters. We also would like to thank the anonymous referees of Springer. They gave us direction and provided us with valuable comments both at a very preliminary stage and at the end of the process. This volume would not have been possible without Federiga Bindi, who as coordinator of the SENT network brought us together with great enthusiasm and sense of purpose and encouraged us in editing this volume. Only a few weeks before completing the volume, Stéphane Vanderveken of the European Personnel Selection Office came to Bolzano to give a keynote to a small conference on teaching the European Union. He made us aware once again of the practical significance and implications of our endeavours. We wish to thank him for his insights and collaborative efforts. Jemma Prior has helped us to streamline the English of each chapter; Irene Bianchi and Gordana Stevancevic collected and formatted the single chapters into one document. We also wish to thank Giuliana Laschi and Fabio Casini of the Punto Europa in Forlì: the wonderful conference organised in Forlì in 2008 allowed many contributors to this volume to meet and to exchange ideas in a way that would not have been possible in purely virtual situations.

153

\section{References}

Bleiklie, I., \& Henkel, M. (Eds.). (2005). Governing knowledge: A study of continuity and change in higher education: A festschrift in honour of Maurice Kogan. Dordrecht: Springer. Politics, 1(1), 5-20.

Cini, M. (2006). The 'state of the art' in EU Studies: From politics to interdisciplinarity (and back again)? Politics, 26(1), 38-46. 


\section{Author's Proof}

S. Baroncelli et al.

195 Cini, M., \& Bourne, A. (Eds.). (2006). Palgrave advances in European Union Studies. Basingstoke: Palgrave.

Holland, M., Jora, S., \& Ryan, P. (Eds.). (2008). The future of European Studies in Asia. Singapore: Asia Europe Foundation.

Keeler, J. (2005). Mapping EU Studies: The evolution from boutique to boom field 1960-2001. Journal of Common Market Studies, 43(3), 551-582.

Korosteleva, E. (2010). Threshold concepts through enactive learning: How effective are they in the study of European politics. International Studies Perspectives, 11, 37-50.

Rosamond, B. (2007). European integration and the social science of EU Studies: The disciplinary politics of a subfield. International Affairs, 83(1), 231-252.

Smith, M. (2003). The state of European Studies: Report commissioned by the Standing Conference of Heads of European Studies. London: Standing Conference of Heads of European Studies.

Wessels, W., Linsenmann, I., \& Hagele, S. (2001, May 31-June 2). A core curriculum on European Integration Studies: Basic assumptions and proposals. Paper presented at the ECSA seventh biennial international conference in Madison, WI. 


\section{Author's Proof}

Chapter No.: 1

\section{Author Queries}

Chapter No.: 1 0002005062
\begin{tabular}{|l|l|l|}
\hline Queries & Details Required & Author's Response \\
\hline AU1 & Please confirm the author group and affiliation details. & \\
\hline AU2 & $\begin{array}{l}\text { Keeler (2001) has been changed to Keeler (2005) as per the } \\
\text { references list. Please check if appropriate. }\end{array}$ & \\
\hline AU3 & Please confirm the corresponding author. & \\
\hline
\end{tabular}

